
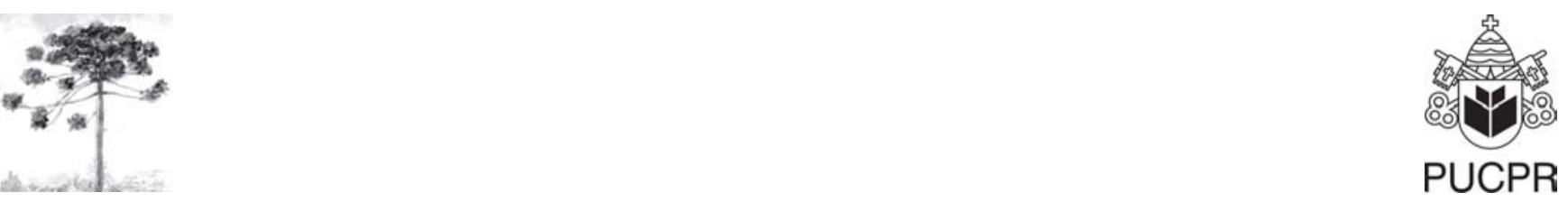

\title{
ESTABLISHING EFFECT OF COMMONLY USED INSECTICIDES FOR APHID CONTROL ON THE INFECTIVITY OF THE ENTOMOPATHOGENIC NEMATODE Steinernema feltiae USING A STREAMLINED SCREENING METHOD
}

Estabelecimento dos efeitos de inseticidas utilizados comumente no controle de afídeos na infectividade do nematóide entomopatogênico Steinernema feltiae utilizando um método de triagem simplificado

\section{Andrew Garnet Steen Cuthbertson', James Jonathan Mathers², Phil Northing ${ }^{3}$, Weiqi Luo ${ }^{4}$, Keith Fredrick Arthur Walters ${ }^{5}$}

\footnotetext{
${ }^{1}$ Senior Research Entomologist, Central Science Laboratory, Sand Hutton, York YO41 1LZ, UK, e-mail: a.cuthbertson@csl.gov.uk

${ }^{2}$ Research Entomologist, Central Science Laboratory, Sand Hutton, York YO41 1LZ, UK, e-mail: j.mathers@csl.gov.uk

${ }^{3}$ Research Entomologist, Central Science Laboratory, Sand Hutton, York YO41 1LZ, UK, e-mail: p.northing@csl.gov.uk

${ }^{4}$ PhD Research Student, Central Science Laboratory, Sand Hutton, York YO41 1LZ, UK, e-mail: w.luo@csl.gov.uk

${ }^{5}$ Research Entomologist, Central Science Laboratory, Sand Hutton, York YO41 1LZ, UK, e-mail: k.walters@csl.gov.uk
}

\begin{abstract}
The entomopathogenic nematode Steinernema feltiae (Filipjev) has been shown to offer much potential for tank-mixing with chemical insecticides in a range of pest control situations. This preliminary study investigated the compatibility of $S$. feltiae with selected insecticides commonly used for the control of aphid pests in UK glasshouse environments. Steinernema feltiae showed a level of direct compatibility with both dimethoate and imidacloprid. Cypermethrin proved non-compatible for direct mixing with S. feltiae. The potential for tank-mixing nematodes with chemical insecticides for aphid control in UK glasshouses is discussed.
\end{abstract}

Keywords: Biological control; Chemical insecticides; Entomopathogenic nematodes; Integrated pest management. 


\section{Resumo}

O nematóide entomopatogênico Steinernema feltiae (Filipjev) tem se demonstrado promissor quanto à possibilidade de mistura com inseticidas químicos para o controle de uma grande gama de pragas. Neste estudo preliminar, foi investigada a compatibilidade do S. feltiae com alguns inseticidas comumente empregados no controle de afídeos, em ambiente de estufa que simula as condições de campo britânicas. Steinernema feltiae demonstrou um nível de compatibilidade direta com dimetoato e imidacloprida. Cipermetrina mostrou-se não compatível para mistura direta com S. feltidae. A potencialidade de emprego de nematóides misturados em tanque com inseticidas químicos para o controle de afídeos em estufas é discutido.

Palavras-chave: Controle biológico; Inseticidas químicos; Nematóides entomopatogênicos; Controle integrado de pragas.

\section{INTRODUCTION}

Insect pathogens such as entomopathogenic nematodes (Rhabditida: Steinernematidae and Heterorhabditidae) have high potential to be used in biological control of a range of various invertebrate pests (1). They have shown particular success in the control of soil based stages of pest lifecycles (2-4). Foliar application of Steinernema feltiae (Filipjev) has been used successfully for the management of the leafminer (Liriomyza buidobrensis (Blanchard), Diptera: Agromyzidae) (5). Strategies incorporating its use have been developed for control of sweetpotato whitefy (Bemisia tabaci Gennadius, Homoptera: Aleyrodidae) (6-9) and its potential for control of thrips (Thrips palmi Karny, Thysanoptera: Thripidae) has also been demonstrated (10-12). The development of integrated pest management (IPM) strategies often requires the use of several biocontrol agents or a range of selected chemical insecticides. Therefore, it is necessary to have an efficient screening method to investigate the potential of incorporating different control agents, biological and/or chemical, into a given IPM strategy as they become available.

Various insecticides used in the United Kingdom (UK) for plant invertebrate pest control are approved for application as a 'tank-mix', in which selected insecticides and/or adjuvants are combined and applied to the plants simultaneously. The nematode Steinernema carpocapsae (Wesier) has been shown to offer much potential for tank-mixing with chemical insecticides for turf pest management (13). Recent research involving $S$. feltiae has shown considerable success in using the nematode in conjunction with chemical insecticides registered in the UK for the control of both B. tabaci on both tomato and verbena foliage (7) and L. buidobrensis on glasshouse lettuce crops (14). This preliminary study investigates the compatibility of $S$. feltiae with selected insecticides commonly used for the control of aphid pests in UK glasshouse environments. This approach, if successful, could allow growers greater flexibility in their spraying regime when more than one pest species is present on crops. Information regarding the compatibility of chemical insecticides and natural predators is vital for the development of IPM strategies against invertebrate pests.

\section{MATERIALS AND METHODS}

\section{Effect of direct exposure of $S$. feltiae to} insecticide solutions on nematode infectivity

A commercial formulation of $S$. feltiae as Nemasys (Becker Underwood (UK) Inc.) was used in all experiments, which were conducted within the chemical efficacy unit at the Central Science Laboratory, York, UK. Infective juveniles (IJ) were suspended (500 nematodes/ml) in the pesticide solutions at their recommended application rates for glasshouse crops in the UK in $50 \mathrm{ml}$ glass beakers following the method of Cuthbertson et al. (7). The insecticides (concentration, active ingredient (a.i.) content, source) tested were as follows: cypermethrin as Toppel 10 (0.062l/1001 water, a.i. 100g/l, United Phosphorous); dimethoate as BASF Dimethoate 
(85ml/1001 water, a.i. $400 \mathrm{~g} / 1, \mathrm{BASF})$; pymetrozine as Chess $(400 \mathrm{~g} / 2001$ water, a.i. $50 \%$ $\mathrm{w} / \mathrm{w}$, Syngenta Bioline); and Imidacloprid as Intercept $70 \mathrm{wg}(0.2 \mathrm{~g} / \mathrm{l}$, a.i. $70 \% \mathrm{w} / \mathrm{w}$, The Scotts Company Ltd.). The beakers were then sealed with parafilm and incubated in the dark for 24 hours at $20^{\circ} \mathrm{C}$, before the solutions were then transferred to a fume cupboard and the contents allowed to settle before removing $10 \mathrm{ml}$ from each container and placing it in a labelled glass beaker.

Two different approaches to establish the effect of the pesticides on the nematode infectivity were investigated:

\section{Trial 1: 'Washed nematodes'}

The nematodes in a subsample were allowed to settle out for at least 20 minutes before the top layer of pesticide was pipetted off and replaced with $20 \mathrm{ml}$ of water. This process was repeated twice more to wash off pesticide residues (15). The volume was adjusted until the final suspension was approximately $150 \mathrm{IJ} / \mathrm{ml}$.

\section{Trial 2: 'Unwashed nematodes'}

The nematodes in the original sample were allowed to settle out for at least 20 minutes after which the upper layer of pesticide was pipetted off and used to reach a $20 \mathrm{ml}$ final suspension of approximately $150 \mathrm{IJ} / \mathrm{ml}$ in the subsample.

\section{Galleria mellonella bioassay}

For each approach ('washed' and 'unwashed' nematodes) Galleria mellonella bioassays were performed following the method of Fan and Hominick (16). Sand was sieved (1.18 $\mathrm{mm}$ aperture), washed, autoclaved and dried before it was used to fill $30 \mathrm{~cm}^{3}$ universal tubes. One $\mathrm{ml}$ nematode suspension (containing approximately $100 \mathrm{IJ} / \mathrm{ml}$ ) was introduced into a $4 \mathrm{~cm}$ deep hole in the same tube that was then filled by shaking the tube. A single G. mellonella larva was placed on the surface of the sand before the tube was sealed, inverted and incubated at $20^{\circ} \mathrm{C}$ for 3 days. After this period the G. mellonella larva was removed from the tube and the sand was rinsed off with water. The larva was maintained on moist filter paper in a Petri dish for a further 24 hours before being dissected and the number of nematodes presented counted and expressed as a percentage of those originally introduced into the tube. There were 10 replicates for each active ingredient and a control of nematode suspension in water, maintained and assessed in the same way, but with the insecticides omitted. Data underwent the non-parametric Kruskal-Wallis rank sum test to compare the effect of the different insecticides.

\section{RESULTS}

Commercially acceptable levels of infectivity were recorded from both the washed and unwashed nematode control groups (Figure 1). The process of washing the control nematodes had no significant effect on infectivity (Kruskal-Wallis chisquare $=0.571 ; \mathrm{df}=1 ; P=0.449)$. Washing the nematodes following exposure to dimethomate and pymetrozine resulted in no significant differences (Kruskal-Willis chi-square $=0.425 ; \mathrm{df}=1 ; P=$ $0.514)$ in infectivity between washed or unwashed samples. Washing the nematodes exposed to imidacloprid significantly increased their infectivity (Kruskal-Willis chi-square $=6.058 ; \mathrm{df}=1 ; P=$ $<0.05)$, however, this infectivity was still significantly lower than the water controls (KruskalWillis chi-square $=5.7$; $\mathrm{df}=1 ; P<0.05)$.

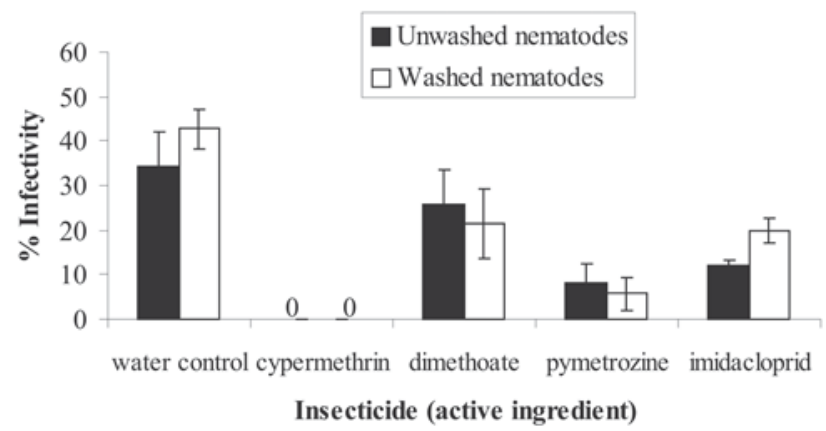

FIGURE 1 - Percentage infectivity of Steinernema feltiae on Galleria mellonella larvae after direct mixing with various insecticides for a 24 hour period

Exposure to cypermethrin resulted in $100 \%$ mortality of nematodes (Figure 1). No significant differences in infectivity of nematodes were recorded between controls and treated following exposure to dimethoate (Kruskal-Willis chi-square $=0.970 ; \mathrm{df}=1 ; P=0.324)$. Tests with 
pymetrozine resulted in infectivity of infective juveniles of below the $15 \%$ threshold, significantly lower than the control groups (Kruskal-Willis chisquare $=7.906 ; \mathrm{df}=1 ; P<0.01)$.

\section{DISCUSSION}

The development of IPM strategies for invertebrate pest control requires much research, not only on the individual biocontrol agent involved, but also on the impact of other nontarget species and the environment. Public awareness of such issues is continuously driving the need for alternative means of pest control to be devised (17). Developing strategies for control of pests on economically important crops requires a rapid method of determining control agent compatibility with selected chemical insecticides.

Formulations of different pesticides may vary in their toxicity to entomopathogenic nematodes, and also, different nematode species can vary in their sensitivity to the same insecticide $(15,18)$. Therefore, the compatibility of nematodes and chemical pesticides for each IPM system needs to be tested individually.

Although a small range of nematode and insecticide combinations have been reported in earlier studies for the control of $B$. tabaci and $L$. buidobrensis $(7,14)$, few studies have been undertaken investigating the impact of chemicals commonly used for aphid control upon S. feltiae. The current study investigated the integration of a number of chemical insecticides commonly used for aphid control in the UK with the entomopathogenic nematode $S$. feltiae.

Washing the control nematodes had no significant effect on infectivity. Any benefit from increased aeration of the water in which the nematodes were suspended was offset by an increased chance of mechanical damage. Washing the 'insecticide treated' nematodes slightly decreased infectivity after exposure to dimethoate and pymetrozine, but again not significantly. However, washing nematodes after exposure to imidacloprid significantly increased their infectivity.

Cypermethrin killed/paralysed the nematodes rendering them useless as biological control agents. Even after washing the nematodes did not regain normal movement and so were unlikely to succeed in invading the galleria larvae.
Cypermethrin therefore is not a viable tank-mix component for $S$. feltiae. Pymetrozine also lowered the infectivity of the nematodes below the acceptable threshold (15\% (7)) and so also cannot be considered as a suitable tank-mix. Only dimethoate produced an acceptable level of nematode infectivity and therefore offers the potential for direct tank-mixing. Further research is now required to investigate the impact of residues of these chemicals on plant foliage on the infectivity of $S$. feltiae leading to the development of economically viable IPM systems against aphid pests in glasshouse environments.

\section{ACKNOWLEDGEMENTS}

The authors thank Becker Underwood (UK) Inc. for supplying the nematodes used in this study. The work was funded by Plant Health Division, Department of Environment Food and Rural Affairs, UK.

\section{REFERENCES}

1. Kaya HK, Gaugler R. Entomopathogenic nematodes. Annual Review of Entomology. 1993;38:181-206.

2. Gouge DH, Hague NGM. Effects of Steinernema feltiae against sciarid flies infesting conifers in a propagation house. Annals of Applied Biology. 1993;122:184-185.

3. Gouge DH, Hague NGM. The development of Steinernema feltiae (Nematode: Steinernematidae) in the sciarid fly Bradysia paupera (Diptera: Sciaridae). Annals of Applied Biology. 1995;126:395-401.

4. Jess S, Bingham JFW. Biological control of sciarid and phorid pests of mushroom with predatory mites from the genus Hypoaspis (Acari: Hypoaspidae) and the entomopathogenic nematode Steinernema feltiae. Bulletin of Entomological Research. 2004;94:159-167.

5. Williams EC, Walters KFA. Foliar application of the entomopathogenic nematode, Steinernema feltiae against leafminers on vegetables. Biocontrol Science and Technology. 2000;10:61-70. 
6. Cuthbertson AGS, Head J, Walters KFA, Gregory SA. The efficacy of the entomopathogenic nematode, Steinernema feltiae, against the immature stages of Bemisia tabaci. Journal of Invertebrate Pathology. 2003;83:267-269.

7. Cuthbertson AGS, Head J, Walters KFA, Murray AWA. The integrated use of chemical insecticides and the entomopathogenic nematode, Steinernema feltiae, for the control of sweetpotato whitefly, Bemisia tabaci. Nematology. 2003;5:713-720.

8. Cuthbertson AGS, Walters KFA, Northing P, Luo W. Efficacy of the entomopathogenic nematode, Steinernema feltiae, against sweetpotato whitefly Bemisia tabaci (Homoptera: Aleyrodidae) under laboratory and glasshouse conditions. Bulletin of Entomological Research. 2007;97:9-14.

9. Cuthbertson AGS, Walters KFA. Evaluation of exposure time of Steinernema feltiae against second instar Bemisia tabaci. Tests of Agrochemicals and Cultivars. 2005;26:34-35.

10. Cuthbertson AGS, North J, Walters KFA. Effect of temperature and host plant leaf morphology on the efficacy of two entomopathogenic biocontrol agents of Thrips palmi (Thysanoptera: Thripidae). Bulletin of Entomological Research. 2005;95:321-327.

11. Smith RM, Cuthbertson AGS, Walters KFA. Extrapolating the use of an entomopathogenic nematode and fungus as control agents for Frankliniella occidentalis to Thrips palmi. Phytoparasitica. 2005;33:436-440.

12. North JP, Cuthbertson AGS, Walters KFA. The efficacy of two entomopathogenic biocontrol agents against adult Thrips palmi (Thysanoptera: Thripidae). Journal of Invertebrate Pathology. 2006;92:77-80.

13. Alumai A, Grewal PS. Tank-Mix compatibility of the entomopathogenic nematodes, Heterorbabditis bacteriophora and Steinernema carpocapsae, with selected chemical pesticides used in turfgrass. Biocontrol Science and Technology. 2004;14:725-730.
14. Head J, Walters KFA, Langton S. The compatibility of the entomopathogenic nematode, Steinernema feltiae and chemical insecticides for the control of the South American leafminer Liriomyza huidobrensis. Biocontrol. 2000;45:345-353.

15. Rovesti L, Deseo KV. Compatibility of chemical pesticides with the entomopathogenic nematodes Steinernema carpocapsae Wesier and S. feltiae Filipjev (Nematoda: Steinernematidae). Nematologia. 1990;36:237-245.

16. Fan X, Hominck WM. Efficiency of the Galleria (wax moth) baiting technique for recovering infective stages of entomopathogenic rhabditids (Steinernematidae and Heterorhabditidae) from soil and sand. Review Nematology. 1991;14:381-387.

17. Cuthbertson AGS, Murchie AK. European red spider mite - an environmental consequence of persistent chemical pesticide application. International Journal of Environmental Science and Technology. 2005;2:287-290.

18. Krishnayya PV, Grewal PS. Effect of neem and selected fungicides on viability and virulence of the entomopathogenic nematode Steinernema feltiae. Biocontrol Science and Technology. 2002;12:259-266.

Recebido: 24/11/2006 Received: 11/24/2006

Aceito: $27 / 12 / 2006$ Accepted: 12/27/2006 